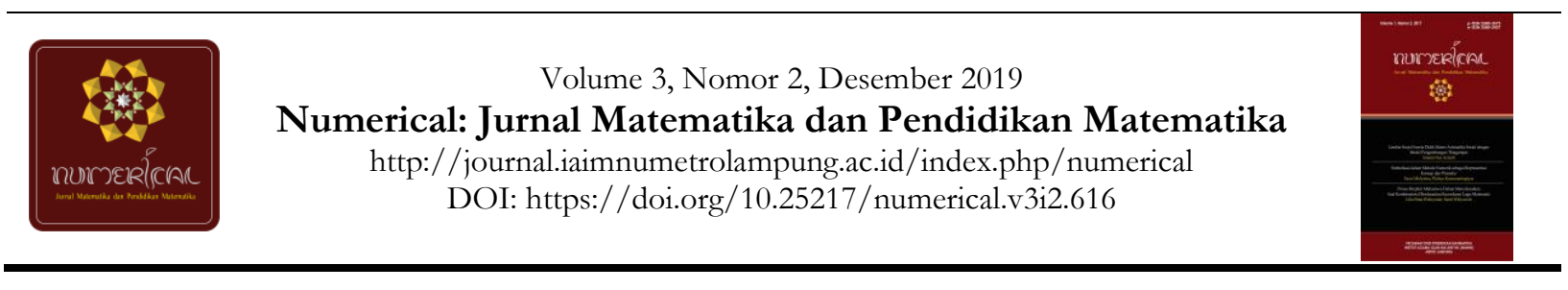

\title{
Pedagogical Content Knowledge (PCK) pada Mahasiswa Calon Guru Matematika
}

\author{
Annis Deshinta Ayuningtyas ${ }^{1}$, Davi Apriandi²
}

${ }^{1}$ Universitas Sarjanawiyata Tamansiswa, Indonesia

2Universitas PGRI Madiun, Indonesia

Correspondence: $\triangle$ annis.ayuningtyas@ustjogja.ac.id

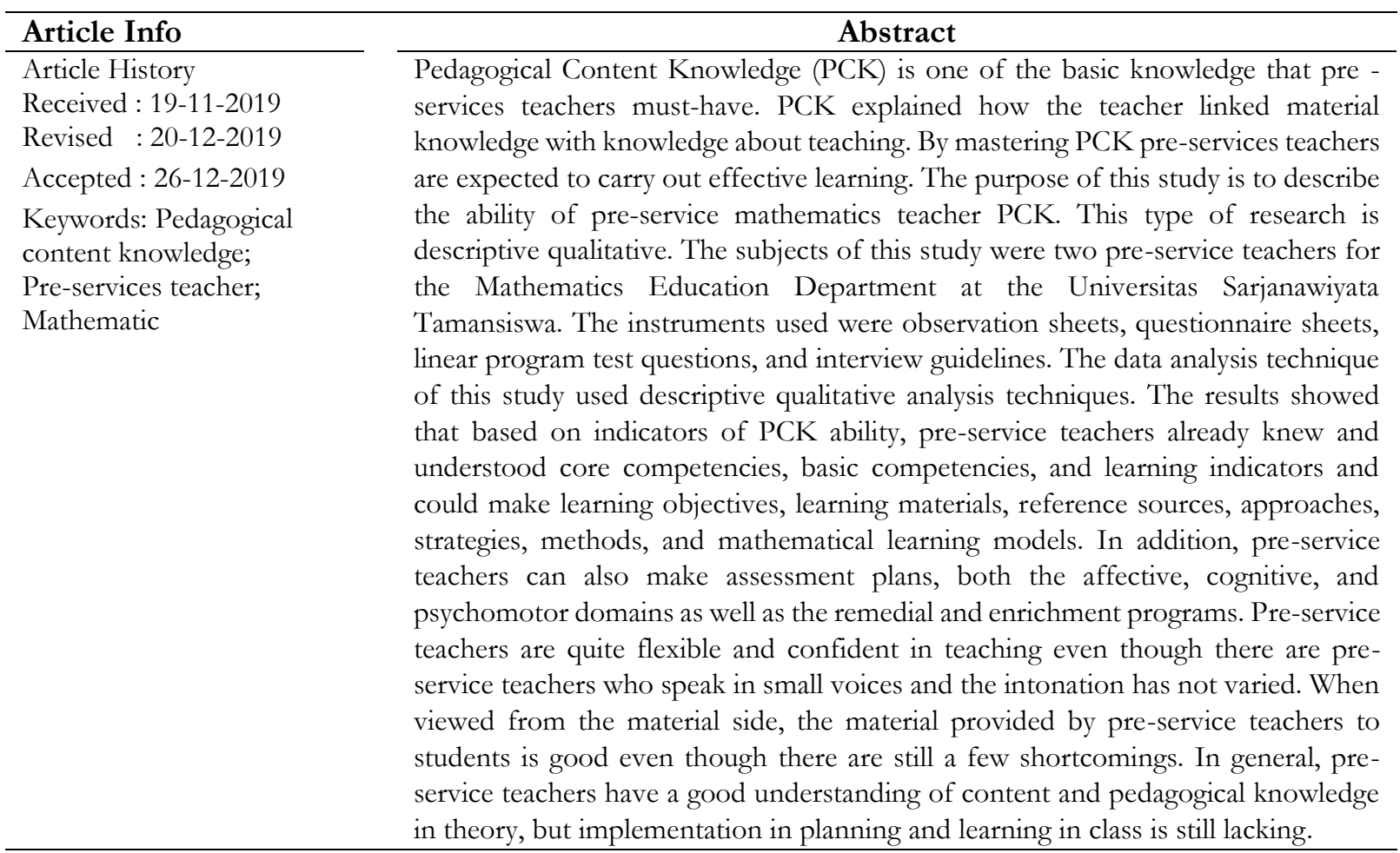

\section{PENDAHULUAN}

Dalam pembelajaran, guru memegang peranan penting dalam menentukan keberhasilan suatu pembelajaran. Guru harus mempunyai pengetahuan dan pemahaman yang mendalam terhadap materi yang akan diajarkannya dan guru juga harus memiliki pengetahuan tentang bagaimana cara mengajarkan materi agar siswa mudah memahami. Kedua kemampuan tersebut tidak dapat dipisahkan dan harus saling terintegrasi. Kemampuan tersebut menurut Shulman [1] merupakan Pedagogical Content Knowledge (PCK). Pedagogical content knowledge terdiri dari dua aspek utama yaitu pengetahuan pedagogik dan pengetahuan konten. Pengetahuan konten dan pengetahuan pedagogik harus dipadukan dalam pembelajaran dan perpaduan itu akan menghasilkan seorang guru yang profesional [2]. Pengetahuan pedagogik berkaitan dengan pengetahuan tentang pedagogik seperti bagaimana mengajarkan materi atau konsep tertentu, bagaimana siswa belajar, bagaimana mengevaluasi dan menilai pemahaman siswa, dll. Yang selanjutnya berkaitan dengan pengetahuan konten tentang penguasaan konsep materi yang akan diajarkan. Shulman [1] mendefinisikan PCK sebagai bentuk representasi dari ide-ide, analogi, ilustrasi, contoh, penjelasan, dan demonstrasi atau dengan kata lain cara yang paling berguna untuk mewakili dan merumuskan suatu materi sehingga dapat dipahami orang lain.

Untuk meningkatkan efektivitas pembelajaran, guru harus memiliki PCK yang baik [3]. PCK memadukan konten dan pedagogik ke dalam pemahaman tentang bagaimana topik tertentu, masalah, atau 
isu, diwakili, dan disesuaikan dengan beragam minat dan kemampuan peserta didik, dan disajikan dalam petunjuk [4]. PCK menjelaskan bagaimana cara guru mengaitkan pengetahuan materi dengan pengetahuan tentang cara mengajar dan mengapa guru memadukan pengetahuan materi menjadi bagian dari proses pembelajaran [5]. Dalam pengembangannya, PCK model Shulman diperluas oleh Marks [6] dengan memasukkan pengetahuan PCK tentang materi pelajaran serta pengetahuan media untuk pengajaran. Namun, dalam sebuah diskusi tentang sumber-sumber PCK, Marks [6] memandang pengembangan PCK sebagai proses integratif yang berputar di sekitar interpretasi pengetahuan subjek-materi dan spesifikasi pengetahuan pedagogik umum, yang berfokus pada dua elemen kunci Shulman. Sedangkan Grossman [7] mempunyai tiga kategori dalam PCK yaitu pengetahuan tentang materi pelajaran, pengetahuan pedagogik umum dan pengetahuan kontekstual. Dari berbagai model PCK tersebut, Kementrian Pendidikan Nasional RI [8] juga telah merumuskan kompetensi yang harus dimiliki guru yang tertuang dalam Permediknas No 16 tahun 2007, yaitu kompetensi pedagogik, kepribadian, social dan profesional. Jika dikaitkan dengan PCK Shulman, kompetensi dalam permendiknas yang sesuai dengan PCK adalah kompetensi pedagogik dan profesional. Terdapat 10 indikator dalam kompetensi pedagogik dan 5 indikator terkait dengan kompetensi profesional yang harus dimiliki guru.

Grossman mengidentifikasi sumber-sumber dari mana saja PCK dihasilkan dan dikembangkan, diantaranya adalah pendidikan guru; dan pengalaman mengajar di kelas [7]. Salah satu lembaga yang fokus dalam pendidikan guru adalah Lembaga Pendidikan Tenaga Kependidikan (LPTK). LPTK berperan dalam mempersiapkan tenaga guru yang kompeten dan profesional [9];[10];[11]. Salah satu LPTK di Provinsi DIY adalah Universitas Sarjanawiyata Tamansiswa (UST). Setiap tahun UST meluluskan ribuan calon guru yang siap bersaing dengan calon guru lain dari berbagai macam LPTK se-Indonesia. UST dalam hal pembekalan kemampuan mahasiswa calon guru dilakukan secara berkesinambungan. Mahasiswa calon guru dibekali tentang teori belajar dan pembelajaran serta materi matematika sekolah yang nanti akan menjadi bekal mereka. Selain memperoleh teori, mahasiswa calon guru juga dibekali praktik mengajar dalam mata kuliah micro teaching. Micro teacbing merupakan program bagi calon guru untuk mengembangkan pengetahuan, ketrampilan dan sikap agar pembelajaran dapat efektif di kelas[12]. Sejalan dengan itu Saban dan Coklar [13] juga menyatakan micro teaching memberikan kesempatan mahasiswa calon guru untuk mengevaluasi kelebihan dan kelemahan mereka dalam mengajar dan mengembangkan kemampuan diri dalam perencanaan, mengatur waktu, mengajukan pertanyaan, mengelola kelas, menggunakan berbagai alat dan bahan selama proses pembelajaran. Pada mata kuliah tersebut mahasiswa calon guru dilatih bagaimana menyiapkan perangkat pembelajaran yang baik, dan bagaimana mengimplementasikan rencana pembelajaran dalam situasi kelas kecil. Setelah mahasiswa lulus pada mata kuliah micro teaching, mahasiswa harus menempuh mata kuliah magang 3 atau praktik pengalaman lapangan (PPL) di sekolah mitra selama 3 bulan. Dalam magang 3, mahasiswa melakukan praktik mengajar secara utuh, melaksanakan tugas-tugas administrasi pendidikan, memberikan layanan terkait dengan kesulitan siswa dalam belajar. Magang 3 bertujuan untuk mengembangkan kompetensi mahasiswa dalam melaksanakan praktik keguruan agar mahasiswa siap menjadi tenaga pendidikan yang profesional [14].

Calon guru yang telah di bekali dengan kemampuan pedagogik dan konten sering kali kesulitan dalam menerapkannya dalam praktik mengajar magang 3 di sekolah. Mahasiswa calon guru yang pengetahuan kontennya kurang baik berakibat pada kurang baiknya PCK mahasiswa tersebut [15], termasuk dalam mata pelajaran matematika. Dalam mengajar matematika, seorang guru harus menguasai konten dengan baik, jika tidak maka akan mengakibatkan kesalahan konsep bagi siswa yang nantinya akan berimbas pada materi matematika berikutnya. Kemampuan ini menjadi suatu keharusan bagi seorang guru, terlebih lagi untuk guru matematika diharuskan mampu memberikan pemahaman materi yang abstrak untuk dapat di serap dengan mudah oleh siswa [16]. Pada penelitian ini akan digali informasi terkait dengan kemampuan PCK mahasiswa calon guru matematika Universitas Sarjanawiyata Tamansiswa selama mereka melaksanakan Magang 3. Indikator PCK yang digunakan dalam penelitian ini merupakan kombinasi dari beberapa ahli yang dijelaskan di atas, adapun indikator PCK sebagai berikut: 1) pengetahuan tentang karakteristik peserta didik dari aspek fisik, moral, spiritual, sosial, kultural, emosional, dan intelektual; 2) Pengetahuan tentang pengembangan kurikulum yang terkait dengan mata pelajaran yang diampu; 3) Pengetahuan tentang materi, struktur, konsep, dan pola pikir keilmuan pada materi program linear; 4) Pengetahuan tentang materi pembelajaran yang diampu secara kreatif; 5) Pengetahuan tentang teori belajar dan prinsip-prinsip pembelajaran yang mendidik; 6) Pengetahuan tentang pemanfaatan teknologi informasi dan komunikasi untuk kepentingan pembelajaran; 7) Pengetahuan tentang pengembangan potensi peserta didik untuk mengaktualisasikan berbagai potensi 
yang dimiliki; 8) Pengetahuan tentang komunikasi secara efektif, empati, dan santun dengan peserta didik; 9) Pengetahuan tentang penyelenggaraan dan pemanfaatan penilaian dan evaluasi proses dan hasil belajar.

\section{METODE PENELITIAN}

Jenis penelitian yang digunakan adalah deskriptif kualitatif. Teknik pengambilan sampel yang digunakan adalah purposive sampling. Subyek penelitian ini adalah 2 mahasiswa calon guru Prodi Pendidikan Matematika Universitas Sarjanawiyata Tamansiswa yang melakukan Magang 3/ PPL di SMA N 2 Bantul. Kedua subjek melakukan praktek mengajar pada materi Program Linear di kelas XI pada bulan Agustus September 2019. Adapun teknik pengumpulan data yang digunakan pada penelitian ini adalah observasi, angket, tes dan wawancara. Secara umum, ketiga teknik tersebut digunakan secara bersamaan dan saling melengkapi. Instrumen yang digunakan adalah lembar observasi untuk menilai cara mengajar mahasiswa di kelas, lembar angket untuk mengetahui kemampuan pedagogis dan konten mahasiswa, soal tes program linear untuk mengetahui kemampuan mahasiswa dalam memahami materi program linear dan pedoman wawancara untuk mengetahui secara langsung mengenai kemampuan pedagogik dan konten mahasiswa. Untuk melihat keabsahan data, dilakukan triangulasi terhadap keempat data yang diperoleh. Teknik analisis data penelitian ini menggunakan teknik analisis deskriptif secara kualitatif. Teknik analisis deskriptif secara kualitatif digunakan untuk mendeskripsikan Pedagogical Content Knowledge (PCK) mahasiswa calon guru matematika.

\section{HASIL DAN PEMBAHASAN}

Berdasarkan penelitian yang dilakukan diperoleh informasi tentang Pedagogical Content Knowledge (PCK) mahasiswa calon guru matematika. Dalam pembahasan ini subjek penelitian diberi kode $\mathrm{M}_{1}$ (subjek 1) dan $\mathrm{M}_{2}$ (subjek 2). Berikut ini deskripsi PCK dari kedua subjek calon guru matematika dari hasil observasi, pemberian angket, tes dan wawancara:

1. Pengetahuan tentang karakteristik peserta didik dari aspek fisik, moral, spiritual, sosial, kultural, emosional, dan intelektual

$\mathrm{M}_{1}$ : Mahasiswa mengetahui karakteristik peserta didik yang berkaitan dengan fisik, intelektual, sosial, dll dengan baik karena sudah melakukan beberapa kali observasi pembelajaran di kelas sebelum mengajar dan wawancara dengan guru untuk memperoleh informasi terkait dengan karakteristik peserta didik. Selain itu, mahasiswa juga sudah cukup baik dalam mengidentifikasi potensi awal, bekal-ajar awal, dan kesulitan peserta didik. Berdasarkan hasil observasi terlihat mahasiswa mengetahui peserta didik mana yang membutuhkan bantuan lebih. Hal ini juga sesuai dengan pengisian angket dan wawancara bahwa mahasiswa melakukan wawancara dengan guru dan observasi di kelas sebelum melakukan pembelajaran. Berikut cuplikan hasil wawancara dengan mahasiswa:

Peneliti : "Apakah Anda mengetahui karakteristik peserta didik?”

Mahasiswa : "Iya bu, saya bertanya kepada guru dan melihat langsung pembelajaran di kelas sebelum mengajar"

$\mathrm{M}_{2}$ : Mahasiswa tidak begitu mengetahui karakteristik peserta didik yang berkaitan dengan fisik, intelektual, sosial karena kurang melakukan observasi, pengetahuan tentang karakteristik peserta didik hanya sebatas pengetahuan berdasarkan kajian umum peserta didik pada usia $16-17$ yang sesuai dengan teori yang telah dipelajari saat kuliah. Tetapi mahasiswa sudah cukup baik dalam mengidentifikasi potensi awal, bekal-ajar awal, dan kesulitan peserta didik. Berdasarkan hasil observasi terlihat mahasiswa ketika berkeliling kelas tidak begitu mengenal karakteristik peserta didik. Hal ini juga sesuai dengan pengisian angket dan wawancara bahwa mahasiswa tidak melakukan wawancara dengan guru dan observasi di kelas sebelum melakukan pembelajaran. Mahasiswa hanya mengandalkan teori tentang perkembangan kognitif peserta didik. Berikut cuplikan hasil wawancara dengan mahasiswa:

Peneliti : "Apakah Anda mengetahui karakteristik peserta didik?"

Mahasiswa : "Tidak begitu bu karena saya hanya membaca teori tentang perkembangan kognitif peserta didik SMA tanpa bertanya kepada guru dan melakukan observasi di kelas sebelum mengajar"

2. Pengetahuan tentang pengembangan kurikulum yang terkait dengan mata pelajaran yang diampu

$\mathrm{M}_{1}$ : Dalam menuliskan RPP yang dibuat sebelum mengajar, mahasiswa sudah dapat menentukan kompetensi inti dan kompetensi dasar yang sesuai dengan silabus mata pelajaran matematika Kurikulum 
2013. Selain itu, mahasiswa juga sudah bisa menentukan tujuan pembelajaran yang sesuai dengan indikator pembelajaran, dapat menentukan pengalaman belajar yang sesuai dengan karakteristik peserta didik dan materi yang dipelajari. Mahasiswa juga sudah menata atau mengurutkan materi program linear sesuai dengan pengetahuan awal peserta didik dengan cara membuat peta konsep walaupun masih ada kekurangan dalam mengurutkan materi. Mahasiswa masih belum bisa memperkirakan cakupan materi dan tingkat kesulitan materi dengan alokasi waktu yang telah ditetapkan. Referensi yang dipakai mahasiswa dalam menyiapkan materi program linear referensi yang baru dan sesuai dengan materi Kurikulum 2013. Mahasiswa menggunakan power point dalam menyampaikan materi program linear. Rancangan penilaian yang berupa kisi - kisi, soal, dan penyelesaian juga sudah dibuat mahasiswa. Berdasarkan hasil observasi terlihat mahasiswa sudah mengumpulkan RPP kepada guru dan peneliti. Hal ini juga sesuai dengan pengisian angket dan wawancara bahwa mahasiswa membuat silabus dan RPP sebelum melakukan pembelajaran. Membuat urutan materi. Berikut cuplikan hasil wawancara dengan mahasiswa:

Peneliti : "Apakah Anda mengembangkan kurikulum yang terkait dengan mata pelajaran yang diampu?"

Mahasiswa : "Iya bu, saya membuat menentukan silabus yang digunakan dan membuat RPP sesuai dengan materi yang akan diajarkan. Saya membuat urutan materi tetapi waktunya kurang saat diterapkan di kelas. Saya juga membuat power point untuk mengajar di kelas."

Sebelum mengajar, mahasiswa membuat RPP terlebih dahulu. Dalam membuat RPP mahasiswa sudah dapat menentukan kompetensi inti dan kompetensi dasar yang sesuai dengan silabus mata pelajaran matematika Kurikulum 2013. Selain itu, mahasiswa juga sudah bisa menentukan tujuan pembelajaran yang sesuai dengan indikator pembelajaran, dapat menentukan pengalaman belajar yang sesuai dengan karakteristik peserta didik dan materi yang dipelajari. Mahasiswa belum menata atau mengurutkan materi program linear yang sesuai dengan pengetahuan awal peserta didik. Mahasiswa tidak membuat peta konsep materi program linear terlebih dahulu sebelum mengajar. Mahasiswa masih belum bisa memperkirakan cakupan materi dan tingkat kesulitan materi dengan alokasi waktu yang telah ditetapkan. Referensi yang dipakai mahasiswa dalam menyiapkan materi program linear referensi yang baru dan sesuai dengan materi Kurikulum 2013. Mahasiswa juga mencari referensi dari youtube. Mahasiswa menggunakan powerpoint dalam menyampaikan materi program linear. Rancangan penilaian yang berupa kisi - kisi, soal, dan penyelesaian juga sudah dibuat mahasiswa. Berdasarkan hasil observasi terlihat mahasiswa sudah mengumpulkan RPP kepada guru dan peneliti. Hal ini juga sesuai dengan pengisian angket dan wawancara bahwa mahasiswa membuat silabus dan RPP sebelum melakukan pembelajaran. Mahasiswa tidak membuat urutan materi sebagai dasar mengajar sehingga terlihat ada penyampaian materi yang terbalik. Berikut cuplikan hasil wawancara dengan mahasiswa:

Peneliti : "Apakah Anda mengembangkan kurikulum yang terkait dengan mata pelajaran yang diampu?"

Mahasiswa : "Iya bu, saya membuat menentukan silabus yang digunakan dan membuat RPP sesuai dengan materi yang akan diajarkan. Saya tidak membuat urutan materi karena tidak terpikir membuat urutan materi. Saya mencari referensi materi dna latihan soal lewat youtube."

3. Pengetahuan tentang materi, struktur, konsep, dan pola pikir keilmuan pada materi program linear $\mathrm{M}_{1}$ : Mahasiswa sudah mengetahui materi dan konsep materi program linear tapi belum bisa menuliskan dengan benar tentang faktual, konseptual, prosedural, dan metakognitif materi program linear pada materi pelajaran yang tercantum pada RPP. Mahasiswa sudah membuat peta konsep materi program linear tetapi masih ada beberapa kekurangan.

Berdasarkan observasi, mahasiswa tidak mengajarkan materi prasyarat program linear pada peserta didik. Ketika diberi tes program linear mahasiswa masih belum menuliskan materi prasyarat lain yaitu sistem persamaan linear dua variabel. Selain itu, mahasiswa salah menuliskan peta konsep dimana setelah menggambar grafik bukan menentukan sistem pertidaksamaan linear dua variabel dari daerah penyelesaian, tetapi seharusnya menentukan titik sudut dari daerah penyelesaian. Hal tersebut juga terlihat pada pengisian angket oleh mahasiswa. Kesalahan pembuatan peta konsep tersebut dikonfirmasi dengan melakukan wawancara terhadap mahasiswa. Berikut cuplikan wawancara terhadap mahasiswa : 
Peneliti : "Berdasarkan hasil tes, mengapa Anda tidak menuliskan beberapa materi prasyarat dan terbalik menuliskan langkah penyelesaian?"

Mahasiswa : "Saya lupa beberapa materi prasyaratnya bu. Saya langsung menuliskan materi apa saja pada program linear. Saya salah menuliskan langkah penyelesaian saat tes tadi tapi pada saat di kelas saya sudah benar bu."

$\mathrm{M}_{2}$ : Mahasiswa sudah mengetahui materi dan konsep materi program linear tetapi belum bisa menuliskan dengan benar tentang faktual, konseptual, prosedural, dan metakognitif materi program linear pada materi pelajaran yang tercantum pada RPP. Mahasiswa tidak membuat peta konsep materi program linear sebelum mengajarkan materinya. Setelah dilakukan wawancara dan tes tertulis tentang peta konsep mahasiswa tidak menuliskan peta konsep karena tidak terpikirkan untuk menuliskan peta konsep. Setelah diminta membuat peta konsep, berikut ini adalah peta konsep yang dibuat oleh subjek $\mathrm{M}_{2}$ :

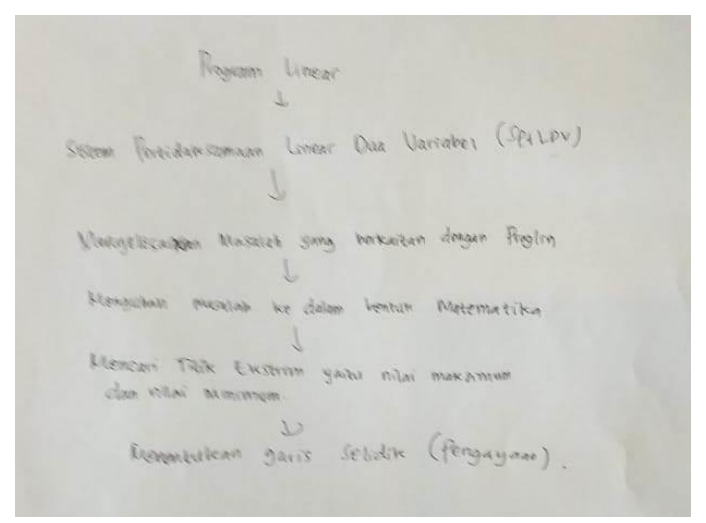

Gambar 1. Peta Konsep Subjek $\mathrm{M}_{2}$

Berdasarkan observasi, mahasiswa tidak mengajarkan materi prasyarat program linear pada peserta didik. Ketika diberi tes program linear Mahasiswa masih belum menuliskan materi prasyarat lain yaitu sistem persamaan linear dua variabel. Mahasiswa juga tidak menuliskan langkah menggambar grafik untuk menyelesaikan masalah program linear pada peta konsep. Hal tersebut juga terlihat pada pengisian angket oleh mahasiswa. Kesalahan pembuatan peta konsep tersebut dikonfirmasi dengan melakukan wawancara terhadap mahasiswa. Berikut cuplikan wawancara terhadap mahasiswa :

Peneliti : "Berdasarkan hasil tes, mengapa Anda tidak menuliskan beberapa materi prasyarat ada langkah penyelesaian yang tidak tertulis?"

Mahasiswa : "Saya lupa beberapa materi prasyaratnya bu. Saat tes tadi saya lupa tidak menuliskan langkah menggambar grafik tapi saat mengajar di kelas saya mengajarkan langkah menggambar grafik."

4. Pengetahuan tentang materi pembelajaran yang diampu secara kreatif

Masalah program linear dapat diselesaikan menggunakan beberapa cara misalnya metode grafik (metode titik sudut dan metode garis selidik) dan metode simpleks. Penggunaan metode grafik hanya terbatas pada masalah program linear dua variabel sedangkan untuk menyelesaikan masalah program linear dengan lebih dari dua variabel bisa menggunakan metode simpleks. Sesuai dengan silabus pada Kurikulum 2013, yang dipelajari pada materi program linear untuk kelas XI SMA adalah penyelesaian masalah program linear dengan menggunakan metode grafik (metode titik sudut) sedangkan untuk pengayaan menggunakan metode garis selidik.

$\mathrm{M}_{1} \& \mathrm{M}_{2}$ : Berdasarkan hasil observasi, mahasiswa sudah bisa memilih mana saja materi program linear yang dipelajari di jenjang SMA kelas XI sesuai dengan tingkat perkembangan peserta didik pada usia 16 - 17 tahun serta dapat mengurutkan materi secara sistematik dan logis walaupun masih ada beberapa kesalahan. Mahasiswa kurang kreatif dalam mengolah materi program linear. Materi dan latihan soal yang dibuat mahasiswa cenderung kurang bervariasi. Hal tersebut didukung dengan hasil pengisian angket tentang pernyataan penguasaan materi pembelajaran. Ketika tes program linear, kedua mahasiswa diminta mengerjakan 2 soal program linear untuk mengetahui pemahaman mahasiswa terkait materi tersebut. Dari hasil pekerjaan kedua mahasiswa diperoleh hasil sebagai berikut: 
Numerical: Jurnal Matematika dan Pendidikan Matematika, Vol. 3 No. 2 Desember 2019,119-130

Annis Deshinta Ayuningtyas, Davi Apriandi

Soal No. 1

Seorang penderita obesitas memperoleh anjuran dari dokter ahli gizi untuk melakukan diet khusus menggunakan tiga jenis makanan yaitu A, B, C. Setiap box makanan A terdiri dari 20 unit kalsium, 10 unit zat besi, 10 unit vitamin, dan 4 unit karbohidrat. Setiap box makanan B terdiri dari 10 unit kalsium, 10 unit zat besi, 20 unit vitamin, dan 6 unit karbohidrat. Setiap box makanan $C$ terdiri dari 10 unit kalsium, 10 unit zat besi, 10 unit vitamin, dan 8 unit karbohidrat. Orang tersebut melakukan diet dengan mengonsumsi setidaknya 300 unit kalsium, 200 unit zat besi, 240 unit vitamin A, dan maksimal 30 unit karbohidrat. Harga untuk setiap box makanan A Rp 60.000,00, tiap box makanan B seharga Rp 40.000,00, dan Rp 80.000,00 untuk setiap box makanan C. Orang tersebut ingin memenuhi anjuran dokter ahli gizi tetapi juga ingin meminimalkan biaya pembelian makanan tersebut. Susunlah model matematika masalah tersebut dan tuliskan konsep matematika yang digunakan!

Jawaban $\mathrm{M}_{1}$

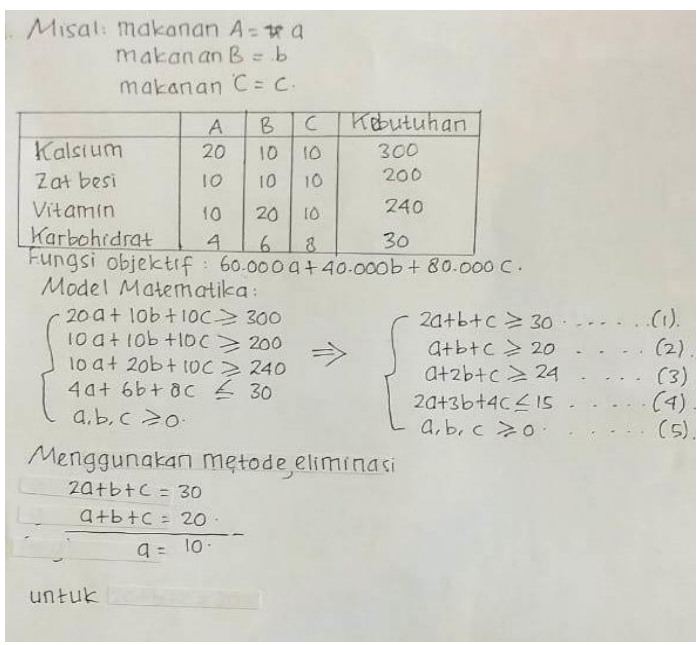

Gambar 2. Hasil Pekerjaan $\mathbf{M}_{1}$ pada Soal 1

Berdasarkan hasil tes, $\mathrm{M}_{1}$ dapat menuliskan apa yang diketahui dengan menggunakan tabel meskipun ada bagian dari soal yang tidak tertulis di tabel serta dapat menuliskan model matematika walaupun ada beberapa kekurangan dalam penulisannya tetapi inti jawabannya sudah benar. Mahasiswa belum bisa menuliskan konsep matematika yang digunakan. Berikut cuplikan wawancara terhadap mahasiswa:

Peneliti : "Mengapa Anda tidak lengkap dalam menjawab soal nomor 1?"

Mahasiswa : "Untuk besar harga yang dikenakan tidak saya tuliskan karena sudah ada di soal. Saya tidak menuliskan konsep matematika yang digunakan karena lupa."

Jawaban M2:

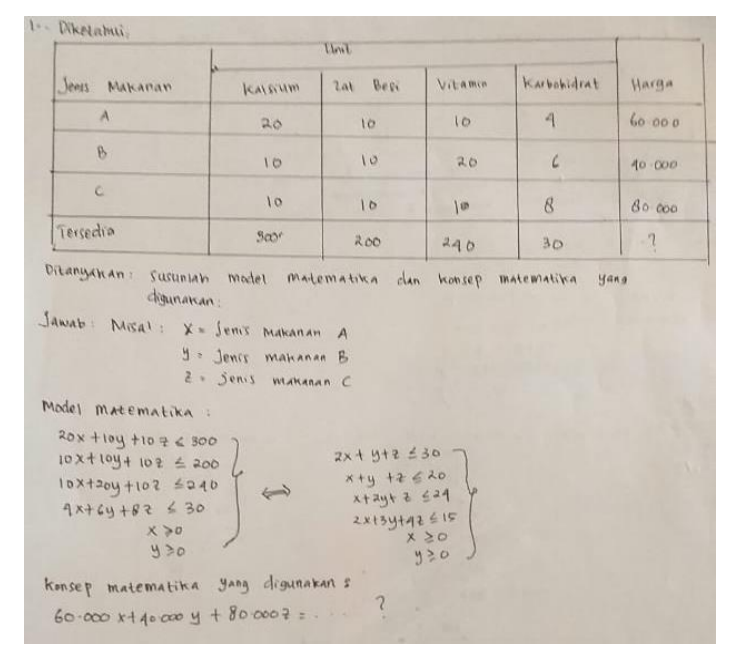

Gambar 3. Hasil Pekerjaan $\mathrm{M}_{2}$ pada Soal 1 
Berdasarkan hasil tes, M2 dapat menuliskan apa yang diketahui dan dituliskan dengan lengkap pada tabel dan dapat menuliskan model matematika tetapi lupa menuliskan fungsi obyektif model program linear. Mahasiswa belum bisa menuliskan konsep matematika yang digunakan. Berikut cuplikan wawancara terhadap mahasiswa:

Peneliti : "Mengapa Anda tidak lengkap dalam menjawab soal nomor 1?"

Mahasiswa : "Untuk besar harga yang dikenakan tidak saya tuliskan karena sudah ada di soal. Saya salah menuliskan konsep matematika yang digunakan karena bingung menjawabnya."

Soal No. 2

Sebuah Home Industry membuat Kue Putri Salju dan Kue Nastar. Kue Putri Salju memerlukan $2 \mathrm{~kg}$ tepung terigu, $1 \mathrm{~kg}$ gula pasir, dan $1 \mathrm{~kg}$ mentega. Kue Nastar membutuhkan $3 \mathrm{~kg}$ tepung terigu, $2 \mathrm{~kg}$ gula pasir, dan $1 \mathrm{~kg}$ mentega. Toko tersebut mempunyai persediaan $300 \mathrm{~kg}$ tepung terigu, $160 \mathrm{~kg}$ gula pasir, dan $120 \mathrm{~kg}$ mentega. Jika satu toples Kue Putri Salju dijual dengan harga Rp 30.000,00 dan satu toples Kue Nastar dijual dengan harga Rp 50.000,00 maka berapa jumlah toples Kue Putri Salju dan Kue Nastar harus dibuat agar diperoleh pendapatan maksimum? Berapa pendapatan maksimum yang diperoleh? Tuliskan konsep atau rumus matematika yang digunakan dalam setiap langkah penyelesaian!

Jawaban $\mathrm{M}_{1}$ :

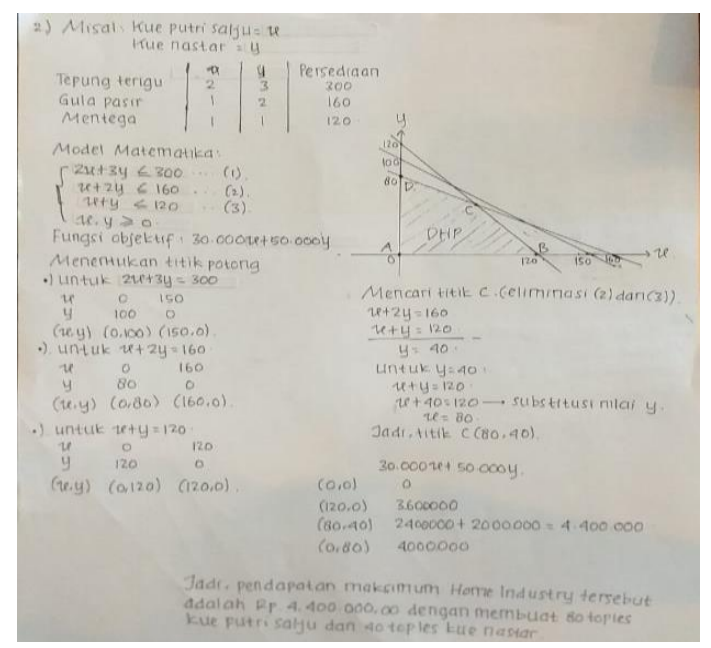

Gambar 4. Hasil Pekerjaan $\mathrm{M}_{1}$ pada Soal 2

Berdasarkan hasil tes, $\mathrm{M}_{1}$ dapat menuliskan apa yang diketahui dengan menggunakan tabel meskipun ada bagian dari soal yang tidak tertulis di tabel serta dapat menuliskan model matematika walaupun ada penulisan yang terbalik urutannya tetapi inti jawabannya sudah benar. Mahasiswa bisa menyelesaikan soal tersebut dengan menggunakan metode grafik (metode titik sudut) dan dapat memberikan kesimpulan dari jawaban. Mahasiswa belum bisa menuliskan konsep matematika yang digunakan. Berikut cuplikan wawancara terhadap mahasiswa:

Peneliti : "Mengapa Anda tidak lengkap dalam menjawab soal nomor 2?"

Mahasiswa : "Untuk harga kue tidak saya tuliskan karena sudah ada di soal. Saya tidak menuliskan konsep matematika yang digunakan karena lupa." 
Jawaban M2:

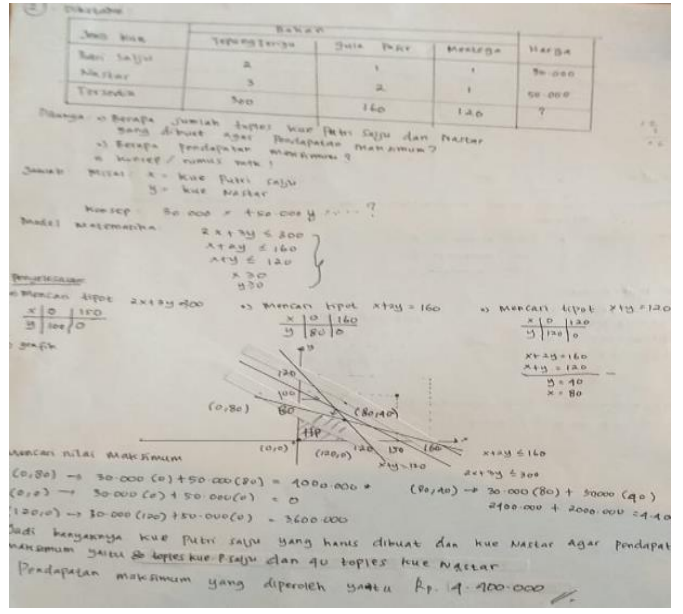

Gambar 5. Hasil Pekerjaan $\mathrm{M}_{2}$ pada Soal 2

Berdasarkan hasil tes, $\mathrm{M}_{2}$ dapat menuliskan apa yang diketahui dan dituliskan dengan lengkap pada tabel. Selain itu, $\mathrm{M}_{2}$ juga menuliskan apa saja yang ditanyakan. Mahasiswa dapat menuliskan model matematika tetapi lupa menuliskan fungsi obyektif model program linear. Mahasiswa bisa menyelesaikan soal tersebut dengan menggunakan metode grafik (metode titik sudut) dan dapat memberikan kesimpulan dari jawaban. Mahasiswa belum bisa menuliskan konsep matematika yang digunakan. Berikut cuplikan wawancara terhadap mahasiswa:

Peneliti : :Mengapa Anda tidak lengkap dalam menjawab soal nomor 2?"

Mahasiswa : "Saya lupa menuliskan fungsi obyektif yang terbentuk. Saya tidak menuliskan konsep matematika yang digunakan karena saya bingung menjawabnya."

5. Pengetahuan tentang teori belajar dan prinsip-prinsip pembelajaran yang mendidik

$\mathrm{M}_{1} \& \mathrm{M}_{2}$ : Berdasarkan hasil pengisian angket, sebenarnya mahasiswa cukup mengetahui dan memahami berbagai teori belajar dan prinsip - prinsip pembelajaran tetapi belum bisa menentukan teori belajar yang cocok dan sesuai dengan materi program linear dikarenakan mahasiswa kurang mendalam dalam memahami berbagai teori belajar sehingga mudah lupa dan tidak memanfaatkan teori belajar tersebut. Dalam proses pembelajaran di kelas mahasiswa juga kurang variatif dalam menerapkan berbagai pendekatan, strategi, metode, dan model pembelajaran. Mahasiswa hanya menerapkan model pembelajaran langsung dengan bantuan power point. Setelah dilakukan wawancara sebenarnya mahasiswa mengetahui tentang berbagai pendekatan, strategi, metode, dan model yang dapat diterapkan dalam pembelajaran matematika tetapi tidak terpikirkan menggunakannya. Berikut cuplikan wawancara peneliti dengan mahasiswa:

Peneliti : "Apakah Anda memahami teori belajar serta model pembelajaran kemudian menerapkannya di kelas?"

$\mathrm{M}_{1} \quad$ : "Saya mengetahui teori belajar dan beberapa model pembelajaran tetapi tidak terpikirkan oleh saya untuk diterapkan."

$\mathrm{M}_{2} \quad$ : "Saya mengetahui teori belajar dan beberapa model pembelajaran walau tidak begitu menguasai tetapi saya tidak menerapkan saat pembelajaran karena tidak terpikirkan untuk menggunakannya."

6. Pengetahuan tentang pemanfaatan teknologi informasi dan komunikasi untuk kepentingan pembelajaran $\mathrm{M}_{1} \& \mathrm{M}_{2}$ : Berdasarkan hasil observasi dan pengisian angket, mahasiswa sudah memanfaatkan teknologi dalam berkomunikasi dengan peserta didik dan untuk pengembangan diri saat mengajar. Mahasiswa menggunakan power point saat menyampaikan materi dan memberikan tugas. Dalam proses pembuatan RPP ataupun Lembar Kerja Peserta Didik (LKPD) mahasiswa juga menggunakan minimal Microsoft Word dengan menggunakan ornamen yang bermacam-macam agar menarik minat peserta didik untuk belajar. Berikut cuplikan wawancara peneliti dengan mahasiswa:

Peneliti : "Apakah Anda memanfaatkan teknologi informasi dan komunikasi saat mengajar?" 
$\mathrm{M}_{1} \quad$ : "Saya menggunakan power point saat mengajar dan membuat sendiri LKPD untuk peserta didik."

$\mathrm{M}_{2} \quad$ : "Saya menggunakan power point saat mengajar. Selain itu saya mencari referensi materi dan latihan soal di Google dan Youtube."

7. Pengetahuan tentang pengembangan potensi peserta didik untuk mengaktualisasikan berbagai potensi yang dimiliki

$\mathrm{M}_{1}$ : Berdasarkan hasil pengisian angket, mahasiswa menyediakan berbagai kegiatan pembelajaran untuk mendorong dan mengaktualisasikan potensi peserta didik serta kreativitasnya untuk mencapai prestasi secara optimal. Mahasiswa melakukan kegiatan pembelajaran matematika yang sistematis dan sesuai dengan karakteristik dan kebutuhan peserta didik. Berdasarkan hasil observasi, mahasiswa memberi materi, contoh soal, dan latihan soal serta menggunakan media pembelajaran dan metode atau model pembelajaran yang memudahkan peserta didik untuk memahami materi seperti mengaitkan antara pembelajaran di kelas dengan masalah kontekstual. Selain itu, model pembelajaran yang digunakan memungkinkan peserta didik terlibat aktif dalam pembelajaran matematika sehingga kelas akan terasa santai namun kondusif. Pemberian kebebasan berpendapat setiap peserta didik untuk mempresentasikan hasil pekerjaannya dalam mengerjakan soal meskipun jawabannya salah sehingga siswa lainnya akan tahu letak kesalahan dan cara mengerjakan soal yang benar. Berikut cuplikan wawancara peneliti dengan mahasiswa :

Peneliti : "Bagaimana Anda mengembangkan potensi peserta didik untuk mengaktualisasikan berbagai potensi yang dimiliki peserta didik?”

Mahasiswa : "Saya memberikan kegiatan yang mendorong peserta didik mengaktualisasikan potensinya dengan cara memberikan soal kemudian meminta siswa mempresentasikan jawabannya.”

$\mathrm{M}_{2}$ : Berdasarkan hasil pengisian angket, mahasiswa menyediakan berbagai kegiatan pembelajaran untuk mendorong dan mengaktualisasikan potensi peserta didik serta kreativitasnya untuk mencapai prestasi secara optimal. Berdasarkan observasi, mahasiswa memberikan tugas individual dan bebas bertanya, memberikan latihan soal untuk dikerjakan di papan tulis dengan metode sukarela (tidak ditunjuk mahasiswa) dan mahasiswa memberikan tugas / PR kepada peserta didik. Dalam pembelajaran matematika peserta didik berdiskusi dalam kelompok, mahasiswa juga memberikan pertanyaan dengan cepat sehingga peserta didik meminta penjelasan lebih. Selain itu, mahasiswa memberikan soal atau pertanyaan yang berhubungan dengan kehidupan sehari - hari. Berikut cuplikan wawancara peneliti dengan mahasiswa :

Peneliti : "Bagaimana Anda mengembangkan potensi peserta didik untuk mengaktualisasikan berbagai potensi yang dimiliki peserta didik?"

Mahasiswa : "Saya mendorong peserta didik mengaktualisasikan potensinya dengan cara memberikan tugas individu dan latihan soal yang berkaitan dengan kehidupan sehari-hari kemudian meminta siswa menuliskan jawabannya di papan tulis secara sukarela."

8. Pengetahuan tentang komunikasi secara efektif, empati, dan santun dengan peserta didik

$\mathrm{M}_{1}$ : Berdasarkan hasil pengisian angket dan wawancara, mahasiswa mengetahui berbagai strategi berkomunikasi baik lisan maupun tulisan yang sesuai dengan karakteristik dan tingkat perkembangan peserta didik. Tetapi mahasiswa belum maksimal dalam menerapkan komunikasi yang efektif dengan peserta didik dengan bahasa yang khas. Berdasarkan hasil observasi, mahasiswa masih belajar berinteraksi dengan peserta didik dalam pembelajaran. Suara $\mathrm{M}_{1}$ pelan sehingga peserta didik yang duduk di bangku belakang kurang jelas yang berakibat peserta didik selalu bertanya kembali setelah dijelaskan. Selain itu, intonasi yang digunakan $\mathrm{M}_{1}$ dalam berbicara masih monoton. Mahasiswa $\mathrm{M}_{1}$ sudah diberi saran terkait penggunaan bahasa dan berusaha memperbaiki kekurangannya. Walaupun mahasiswa masih ada kekurangan dalam hal suara tetapi untuk penampilan gerak mahasiswa luwes dan percaya diri dalam mengajar. Berikut cuplikan wawancara peneliti dengan mahasiswa:

Peneliti : "Apakah Anda mengetahui dan menerapkan komunikasi yang efektif untuk mengajar di kelas?"

Mahasiswa : "Saya mengetahui cara berkomunikasi di kelas. Saya mengajar menggunakan bahasa Indonesia tapi ternyata suara saya pelan. Setelah diberi masukan seperti itu saya berusaha berbicara lebih keras lagi." 
$\mathrm{M}_{2}$ : Berdasarkan hasil pengisian angket dan wawancara, mahasiswa mengetahui berbagai strategi berkomunikasi baik lisan maupun tulisan yang sesuai dengan karakteristik dan tingkat perkembangan peserta didik. Tetapi mahasiswa belum maksimal dalam menerapkan komunikasi yang efektif dengan peserta didik dengan bahasa yang khas. Mahasiswa masih belajar berinteraksi dengan peserta didik dalam pembelajaran. Suara $\mathrm{M}_{2}$ keras dan jelas tetapi kadang masih terlalu cepat. Selain itu, intonasi yang digunakan $\mathrm{M}_{2}$ dalam berbicara lumayan bervariasi. Mahasiswa $\mathrm{M}_{2}$ sudah diberi saran terkait penggunaan bahasa dan berusaha memperbaiki kekurangannya. Walaupun mahasiswa masih ada kekurangan dalam kecepatan berbicara tetapi untuk penampilan gerak mahasiswa luwes dan percaya diri dalam mengajar. Berikut cuplikan wawancara peneliti dengan mahasiswa:

Peneliti : "Apakah Anda mengetahui dan menerapkan komunikasi yang efektif untuk mengajar di kelas?"

Mahasiswa : "Saya mengetahui cara berkomunikasi di kelas. Saya mengajar menggunakan bahasa Indonesia tapi terkadang masih bercampur dengan bahasa daerah. Selain itu, ternyata saya berbicara terlalu cepat intonasinya. Setelah diberi masukan seperti itu saya berusaha berbicara dengan intonasi yang lebih pelan."

9. Pengetahuan tentang penyelenggaraan dan pemanfaatan penilaian dan evaluasi proses dan hasil belajar $\mathrm{M}_{1} \& \mathrm{M}_{2}$ : Berdasarkan hasil pengisian angket, mahasiswa sudah mengetahui prinsip - prinsip penilaian dan evaluasi proses dan hasil belajar yang sesuai dengan karakteristik peserta didik dan karakteristik materi program linear. Mahasiswa juga sudah bisa membuat rancangan dan prosedur penilaian yang sudah tertulis di RPP. Mahasiswa bisa membuat kisi - kisi, soal tes, dan penyelesaian. Mahasiswa membuat rancangan penilaian ranah kognitif, afektif, dan psikomotorik. Berdasarkan observasi, mahasiswa memberikan latihan soal untuk penilaian saat proses pembelajaran dan tes hasil belajar pada peserta didik setelah selesai menyampaikan materi program linear. Walaupun mahasiswa sudah melakukan penilaian tetapi mahasiswa belum bisa memanfaatkan hasil penilaian untuk meningkatkan kualitas pembelajaran. Mahasiswa sudah membuat rencana program remidial dan pengayaan tetapi belum melaksanakan dengan maksimal. Hal tersebut karena waktu yang diberikan guru untuk melakukan pembelajaran terbatas sehingga mahasiswa tidak ada waktu untuk melakukan program remidial dan pengayaan. Berikut cuplikan wawancara peneliti dengan mahasiswa :

Peneliti : "Apakah Anda melaksanakan penilaian dan evaluasi proses dan hasil belajar serta memanfaatkan hasilnya?"

$\mathrm{M}_{1} \quad$ : "Saya membuat rencana penilaian baik kognitif, afektif, maupun psikomotorik tetapi saya belum memanfaatkan hasilnya karena waktu yang kurang. Saya juga membuat rencana pembelajaran remidial dan pengayaan tetapi belum dilaksanakan karena waktu dibatasi oleh guru.।"

$\mathrm{M}_{2} \quad$ : "Saya membuat rencana penilaian tetapi saya belum memanfaatkan hasilnya. Saya juga membuat rencana pembelajaran remidial dan pengayaan tetapi belum dilaksanakan karena waktu yang terbatas."

\section{SIMPULAN DAN SARAN}

Berdasarkan hasil dan pembahasan, dapat disimpulkan bahwa kemampuan Pedagogical Content Knowledge (PCK) mahasiswa calon guru merupakan kombinasi dari pengetahuan pedagogik dan pengetahuan materi. Berdasarkan indikator kemampuan PCK, mahasiswa sudah mengetahui dan memahami kompetensi inti, kompetensi dasar, dan indikator pembelajaran serta dapat membuat tujuan pembelajaran, materi pembelajaran, sumber referensi, pendekatan, strategi, metode, dan model pembelajaran matematika. Selain itu mahasiswa juga sudah bisa membuat rancangan penilaian baik penilaian ranah afektif, kognitif, dan psikomotorik serta program remidial dan pengayaan. Walaupun sudah bisa membuat tetapi masih ada kekurangan, mahasiswa juga bersedia memperbaiki kesalahan tersebut. Mahasiswa sudah cukup luwes dan percaya diri dalam mengajar walaupun ada mahasiswa yang berbicara dengan suara yang kecil dan intonasinya belum bervariasi. Jika dilihat dari sisi materi, materi yang diberikan mahasiswa kepada peserta didik sudah baik walaupun masih ada sedikit kekurangan. Hal ini dikarenakan mahasiswa lupa dengan materi prasyarat yang harus diberikan serta soal yang diberikan juga masih kurang bervariasi. Semua kekurangan yang dibuat mahasiswa masih bisa dimaklumi karena mahasiswa calon guru ini masih pada taraf belajar, yang terpenting mahasiswa mau menerima saran dan memperbaiki kesalahan. 
Beberapa hal yang dapat disarankan terkait hasil penelitian ini adalah bagi mahasiswa yang melaksanakan magang 3 sebaiknya mengimplementasikan teori tentang pengelolaan kelas dengan maksimal, selain itu lebih mengembangkan materi pembelajaran baik dari teori, contoh soal, dan latihan soal sehingga lebih variatif. Peneliti yang lain bisa meneliti mengenai pengetahuan dasar lainnya yang harus dimiliki mahasiswa calon guru.

\section{DAFTAR PUSTAKA}

[1] L. E. E. S. Shulman, "Those Who Understand: Knowledge Growth in Teaching,” Educ. Res., pp. 4 14, 1986.

[2] J. Loughran, P. Mulhall, and A. Berry, "Exploring Pedagogical Content Knowledge in Science Teacher Education," Int. J. Sci. Educ., vol. 30, no. 10, pp. 1301-1320, 2008.

[3] J. Loughran, A. Berry, and P. Mulhall, Understanding and Developing Science Teachers' Pedagogical Content Knowledge, 2nd Edition. Rotterdam: Sense Publishers, 2012.

[4] L. S. Shulman, "Knowledge and Teaching: Foundations of the New Reform," Harv. Educ. Rev., vol. 57, no. 1, pp. 1-23, 1987.

[5] K. F. Cochran, Ja. A. DeRuiter, and R. A. King, "Pedagogical Content Knowing: An Integrative MOdel for Teacher Preparation,” J. Teach. Educ., vol. 44, no. 4, pp. 263-272, 1993.

[6] R. Marks, "Pedagogical Content Knowledge: From a Mathematical Case to a Modified Conception," J. Teach. Educ., vol. 41, no. 3, pp. 3-11, 1990.

[7] J. H. Van Driel, N. Verloop, and W. De Vos, "Developing Science Teachers' Pedagogical Content Knowledge," J. Res. Sci. Teach., vol. 35, no. 6, pp. 673-695, 1998.

[8] Peraturan Menteri Pendidikan Nasional Republik Indonesia, "Standar Kualifikasi Akademik dan Kompetensi Guru," 2007.

[9] A. Rohman, "Peran LPTK Dalam Mempersiapkan Guru yang Kompeten," Jurnal At-Taqaddum, vol. 5, no. 2. pp. 282-301, 2013.

[10] P. B. Caraka and I. Maryani, "Strategi LPTK Dalam Pengembangan Kompetensi Pedagogik Calon Guru," J. Pendidik., vol. 01, no. 02, pp. 96-106, 2016.

[11] S. S. Abdullah, "Kesiapan Mahasiswa LPTK Swasta di Semarang Menjadi Guru Matematika yang Profesional," PYTHAGORAS J. Pendidik. Mat., vol. 12, no. 1, pp. 87-97, 2017.

[12] N. Yigit, "Developing Presentation Skills of Student Teachers Through Micro-Teaching Method," Energy Educ. Sci. Technol. Part B Soc. Educ. Stud., vol. 2, no. 2, pp. 55-74, 2010.

[13] A. Saban and A. N. Coklar, "Pre-Service Teachers' Opinions About The Micro-Teaching Method in Teaching Practise Classes," TOJET Turkish Online J. Educ. Technol., vol. 12, no. 2, pp. 234-240, 2013.

[14] L. Yuliati, "Membangun Pedagogical Content Knowledge Calon Guru Fisika Melalui Praktek Pengalaman Lapangan Berbasis Lesson Study," Momentum Phys. Educ. J., vol. 1, no. 1, pp. 16-30, 2017.

[15] M. Käpylä, J. P. Heikkinen, and T. Asunta, "Influence of Content Knowledge on Pedagogical Content Knowledge: The Case of Teaching Photosynthesis and Plant Growth," Int. J. Sci. Educ., vol. 31, no. 10, pp. 1395-1415, 2009. 
Numerical: Jurnal Matematika dan Pendidikan Matematika, Vol. 3 No. 2 Desember 2019,119-130

Annis Deshinta Ayuningtyas, Davi Apriandi

[Halaman ini sengaja dikosongkan] 